\title{
MULTICULTURALISM IN FRANCE: OVERVIEW, PROBLEMS, CONDITIONS OF INTERNATIONAL IMMIGRANTS AND SECOND GENERATION YOUTH IN FRENCH SOCIETIES
}

\author{
JAHANZEB MUGHAL \\ Assistant Registrar/ Staff Officer \\ The Islamia University of Bahawalpur, Pakistan. \\ Bahawalnagar Campus. \\ Email: jahanzebmughal@yahoo.com
}

\begin{abstract}
The world has become a global village and all nationals have got opportunity to visit various parts of the world due to advancement of travelling and communication technologies for the purpose of trade, education, business or trade. Somehow, the main reason to travel for majority of population stands to earn a good earning that is creating trouble for many nations and France is among top of the list. France has emerged as a multi-cultural nation and many of its societies have been based on multi-cultural intruders. The country is thinking to tackle the issue but all in vein and inacceptable by the concerned. The illegal immigrants are demanding to be issued permanent residence of France and identification cards as per the country rules but most injured nation stands the Muslim societies. The whole Europe looks at Muslims with an eye of hatred and consider them threat to their safety especially after the 9/11 attacks on twin-towers of New York City. Our article depicts highlight on the history of establishment of France as a Multi-cultural nation and the challenges it is being faced with.
\end{abstract}

\section{MULTICULTURALISM}

The culture describes living conditions, trends and norms of a society. It shows how people interact with each other and their spiritual concepts, religion and even dressing also includes in the definition of culture. Therefore, it can be mentioned that a culture is mixture of all above elements of a society. If we talk about a society that contains various societies living together having different beliefs, religions, languages, food and dressings, it is known as multiculturalism in a society (Thomas \& Harper, 2011).

This phenomenon happens naturally. The world has become a global village and many countries have come to know importance of communication technology in this regard. These technologies have brought closer many societies of the world and people 
can now travel to various parts of the world without any difficulty and they start living together. The societies can move either for good and reasonable earnings, seeking peace and prosperity in their lives. Gradually, they start understanding each other and adjust themselves accordingly. The modern world has become the best example of multiculturalism as there is no more unique and single societies living separate on any corner of earth but the societies have become mixture of various ethnic groups and people. However, the concept may have different effects when it comes to different people living in a single society and when different traders try to enter into various societies to launch their business and sales. Though, competition raises in the second concept and this feature also reduces market prices of goods due to stiff competition.

The multiculturalism also brings conflicts and clashes in the societies as people from different belief, religion, language, etc, are living together. It can be named as diversity in societies (Kenan Malik, 2010). The diverse societies can be more productive as compared to the uni-cultural societies. However, these conflicts and clashes are positive and negative on the same time depending upon the situation. The positive aspect is that it leads societies towards creation of law and policies. Each and every member of the society shall abide by these regulations and it shall be implemented on all individuals without any discrimination. According to Burgess \& Tom (2005), multiculturalism promotes integration of many races, cultures, societies and it may be called as "salad bowl", that mixes variety of food items to make it unique eating dish. It tastes greater rather you eat every fruit separately.

\section{HISTORY AND EARLY RULERS OF FRANCE}

France keeps its dominance in the history with full of different wars, revolutions and development. It has been considered major power by both military point of view, economically and politically basis. France keeps its borders with many European countries and covers territory measuring up to 640,679 kilometer with population about 66.6 million. The country has been the habitat for various cultural and ethnic groups like during the Iron Age; it remained in the hands of Gauls who were basically Celtic. Gauls were having huge territory expanding up to present states of Netherlands, Germany, Belgium, France, Northern Italy and few parts of the Western bank of Rhine (Arrowsmith \& Aaron, 2006).

It is very clear from the history that it is now state comprising number of cultures and religions. This region was initially divided into three parts comprising Gallia Celtica, 
Belgica and Aquitania. Later, the state came under the Romans during $123 \mathrm{BC}$. They rules Gaul for about five hundred years until $486 \mathrm{AD}$, when the state was conquered by the Franks. During this stint of time, the original culture, norms and traditions of Celtic Gauls had vanished (Birkhan, 1997).

However, history shows that Gaul was not only the state of Gauls but Greeks also put their outposts around the costs of Mediterranean (Archaeologies of Colonialism, 2010). The Gauls prayed different animals as their Gods and seldom had they also bowed before natural elements like the lakes, rivers, oceans, sun, moon, etc. They nominated "Boar" as the most sacred animal on earth. It could easily been seen at their military uniforms and other installations.

The term "insertion" has specific meaning to the French society that is totally different from the world integration or assimilation. In the French society, international immigrants are still welcomed to their country to seek better life and good paid labor / employment. However, they are still considered aliens "people from other countries" and not considered as part of French society. However, if the international immigrants are to get integrated, they need to leave their primary culture and adopt the French culture. This process is not only difficult for someone but so deeper and longer period of time it takes (Le Bilan, 2006). This process is framed to save the local trends and cultures.

\section{A. MODERN FRANCE}

It can be judged from the history above that this country, at present age, is a combination of various societies and ethnic groups. The modern France holds several fashion shows on mass levels and invites various cultural groups from all around the globe like America, Pakistan, Italy, Germany and many other European countries. These fashion shows are highly appreciated from all participants and guests but can be seen on television on specially framed TV channel "Fashion TV-France".

There has been a lot of criticism on the current France and its cultures because the French revolution was initiated to fight against the international habitants in France but at present, the situation is reverse. It is state of many religious groups like French, Germans, Muslims, Hindus, Christians, etc and the original identity of France has got badly mixed-up. The culture depicts norms, traditions, language and daily life routines of any 
nation but it is totally lost in case of modern France. The major reason may be stood illegal immigration of various nationals in the France for earning purpose (Jary, 1991).

The last two hundred years had been difficult for the French nation including the two World wars. The government has called it mandatory for its people to seek mandatory education of French language in the educational system, military systems and also has developed cultural policies to keep its traditions alive. Despite all such difficulties, the modern France is land of unique language (French), religion and cultures like cuisine, spoken accents and many other local traditions. All other policies like immigration rules, business laws, etc are also been established to promote the French culture.

Mr. Charles de Gaulle, who remained the $18^{\text {th }}$ President of France during the period of 1959 to 1969 , raised his volume to protect the French culture and debated on the issue on various platforms. He also promoted the concept that his country should not rely on any other country for its security and other political and economical matters i.e. America (Edwards, 1974). He was a dominant politician of his time and also initiated the concept of "Politics of Grandeur" that concept not to depend on other states for survivals and got huge popularity in the region.

\section{B. LANGUAGES IN FRANCE}

France is land of various languages like Germany, Italian, French, English, etc. However, after the last two centuries, the Ministry of Education has applied new rules for the school teachers to also teach the students at least two international languages in addition to the French, national language of France. These two languages are German and English and for this purpose, such teachers shall be recruited who knows at least one of these two international languages to educate their students.

The French government runs Ministry of Culture that is solemnly responsible to promote the culture in the country. It was also established by the Ex-President, Mr. Charles de Gaulle during year 1959. There are total about 75 different languages being recognized to be spoken in France and majority belongs to Gallo-Roman languages.

\section{CHALLENGES TO MULTICULTURALISM IN FRANCE}

There are lots of questions that may strike in one's mind regarding what are the reasons to failure of multiculturalism in France? What are the reasons that the integration 
model of France and secularism is working? Does the French society accepts the newly born immigrants of their country and considers them part of their nation?

During the year 1905, French law of "Laicite" was developed to make the church different from the nation. The purpose was to allow people of different faith and religions to worship their own religions and it was also excluded from the French Integration Model (Patrick Weil, 2006).

If we consider the France, a secular state that accepts all the religions and makes no differences then it is somehow wrong. The problem is not being secular state but implementation of laws and requirements of secular state is important. The state should never forget the beliefs of any individual or society living on its soil. The Muslim society is not only being targeted all over the European countries but also in France, that claims to be secular state. During the year 1989, three Muslim girls were expelled from their school to wear the Muslim headscarf. This act was also against the European convention and the same practice was exercised during year 2003, after the terrorist attacks on Twin-towers New York. The law never forces or to be implemented against the religion beliefs and trends. However, if the pressure on those Muslim girls is considered, what could be the consequences? It would be first considered an insult and then violence in the state (Maxim Silverman, 1991).

At present, there are about 5 million Muslims in the France and out of which 35 percent from Algeria, 25 percent from Morocco and 10 percent from Tunisia origin (Henri, 2007). However, the main problem stands there that besides the integration model counts the independence of religions but in this case, this model has failed in France (Henri, 2007).

Another problem that exists in France is the racism. According to Sources, racism has been widely noticed in the employments in France. Till year 2000, the unemployment ratio in the country was 10 percent as compared to the 20 percent among the international immigrants. On the other hand, many poor residences have been established on the outskirts of big cities like the capital city itself. These residences were made for the foreign unemployed immigrants who live in such miserable conditions and have many difficulties even to call police for any assistance. A number of such immigrants are living in these 
areas since long time but still have no possibility to attain the nationality of France (Patrice De Beer, 2006).

According to Mr. Tariq Mehmood (2006), who is the Professor of Sociology, Politics and Public Policy in the University of Bristol and founding director of the University's center for the Study of Ethnicity and citizenship. In this current century the major problem in the two countries, France and Great Britain, is to accept the Muslims in their societies and they do not see them as part of their culture. They treat them as separate nation and separate religion and cultures.

\section{GENERAL SITUATION OF IMMIGRANTS IN FRANCE}

France has always been the country welcoming international immigrants from not only Europe but all around the globe. The Poles and Italians immigrated to France before the World War-II, Spanish and Portuguese during 1950s and 1960s whereas, the Africans during 1970s and 1980s (Le Monde, 2007). The education access is not illegal in France but for illegal immigrants, their children are facing severe problems for being expelled from their schools due to reasons that they do not know names of their parents.

There has been an illegal migration to France and about 200,000 to 400,000 international migrants came illegally to France during 1980s and mostly from West African States. In this connection, the French government took the initiative and provided legal residence permit to about 132000 migrants. However, it was the government of Lionel Jospin, who framed second immigration laws. At this time, about 80,000 migrants were given permission to stay in France on permanent basis out of 150,000 applicants. During the year 2006, around 30,000 applications were approved to stay at France. They were the children of illegal immigrants who were studying in the French schools and out of these about 7000 applicants were also provided with residence facilities in France. However, during the year 2006, the immigration legislation was almost demolished. It allowed the then Minister of Interior, Nicholas Sarkozy to make the number of deportees increased. $\mathrm{He}$ was succeeded in this matter as well and about 23, 831 people were deported from France during year 2006. He again and again expressed his ideas at various platforms and described his targets to deport these immigrants from France (UNHCR, 2006).

Moreover, there has been relaxation in marriage system of French national with the non-French nationals. It was first about 10 years to be allowed to live in France for 
permanent residence and same for marriage but it has now been relaxed to seven years. However, the non-French immigrant must know French language and culture. It also includes the point that the foreign spouse shall now be able to apply for permanent citizenship of France after about 4 years and it was only 2 years in previous rules. This rule has been dismissed by the court of constitution during year 2006 .

The present situation of immigrants in France is little miserable as it is harder for the children of these immigrants are also facing difficulties to become permanent resident of France. However, they can apply for the nationality when they become eighteen years of age. The French calls them second generation youth of immigrants. The situation is under pressure of both political policies and cultural affects of the country. The integration of immigrants and their children who are born in France is major problem and require political solutions (LEED, 2006). The highest successful immigrants are the labors who have options to contribute in the economy of the host country with all their hard work and efforts may find this policy somehow soft in their favor. This may happen adverse to the poor performers and this is going to generate unrest in the immigrant societies and riots in country (Heath and Cheung, 2007). He further adds that there has been no data collection regarding the performance of these immigrants in the France and it is also unknown how many immigrants are still residing in the country. This problem simply requires a policy from the government.

During the year 2005, two young immigrants belonging to Mali and Tunisia were electrocuted as they fled the police in the Parisian suburbs. The death of these two youths triggered huge riots in almost 300 towns and majority of rioters were second generation immigrants.

The government authorities are now conducting surveys to exactly confirm the population of these immigrants, their education and fore-fathers names, etc. This study was never conducted before. When you have no data regarding your population than what policy we can develop and their problems shall remain solution less forever (Pouget, 2007).

As compared to France, UK has totally different policy for the immigrants. Their policy respects the religious beliefs of the immigrants like the Sikh motorcyclists can wear turbans as part of their religious and cultural belief and the Muslim women can wear hijab 
while on duty or at public places while on recreational activities or in the market to purchase their households, etc. The French society takes care of immigrants and treats every national on equality basis. They just only need some tests to become the French national like language test, cultural know how, history of France and its modern affairs, etc (Fabbri, 2003).

The UK immigrants can only provide immigrants community centers and place to live but no permanent residence and this is totally different in the case of French society, you can apply for nationality when reaching age of 18 . Yet there are many concerns like the Muslim girls are being expelled from their schools for wearing hijab / scarf, whereas, it is their religious right to wear it. These situations create riots and generate terrorism activities in the country (Chiswick, 2007).

\section{CONCLUDING REMARKS}

The French society has historical figures and glories during the Iron Age. It brings unique culture and traditions with it and keeps the country unique due to these qualities. Moreover, it is also becoming labor hub for many immigrants and attracts about 100,000 immigrants every year. The government should make the necessary measure and law to protect the legality of these immigrants and recognition of their children in their societies. Provision of equal rights to all citizens is nice work done but yet much is needed to be done as in the case of Muslim students expelled from their schools for mere reason to wearing scarf. It is their religious right and no one can force them to leave. It would be against the European Union convention as well and may create riots in the country. The police must perform its duty well in manner and on equality manner. When there is one law but not for all, it creates terrorism.

\section{REFERENCES}

Arrowsmith, (2006). A Grammar of Ancient Geography: compiled for the Use of King's College School. [Online at]: https://books.google.co.uk/books?id=X1iwAuAJSOcC\&pg=PA48\&dq=Scythia+squ are + miles\&source $=g b s$ toc $r \& h l=e n \# v=0 n e p a g e \& q=g a l l i a \% 20 \& f=f a l s e$

Artan Fuga, (2008). Multiculturalism in France: Evolutions and Challenges. EUROSPHERE working paper series No. 12, $2008 . \quad$ [Online at]: http://eurosphere.uib.no/knowledgebase/workingpapers.htm 
Burgess, Ann Carroll; Burgess, Tom, (2005). Multiculturalism undermines diversity. [Online at]: http://www.theguardian.com/commentisfree/2010/mar/17/multiculturalismdiversity-political-policy

Chiswick, B. R. (1978). The effect of Americanization on the earnings of foreign-born men. Journal of Political Economy, 86 (5).

Chiswick, B. R. (2007). Are there gender and country of origin differences in immigrant labor market outcomes across European destinations? Journal of Population Economics, 20 (3).

Fabbri, F. (2003). Language proficiency and labour market performance of immigrants in the UK. Economic Journal, 113 (489).

Henri Astier, (2007). "Ghettos Shackes French Muslims". Courtesy of BBC News. [Online at]: http://news.bbc.co.uk/2/hi/europe/4375910.stm.

Jary, D. and J. Jary. (1991). The HarperCollins Dictionary of Sociology, page 101

Kendrick, Thomas D. (1966). The Druids: A study in Keltic prehistory.

Kolodziej, Edward A (1974). French International Policy under de Gaulle and Pompidou: The Politics of Grandeur.

Maxim Silverman (1991). "Introduction" in maxim Silverman: Race, Discourse and Power in France.

Michael Dietler, (2010). Archaeologies of Colonialism: Consumption, Entanglement, and Violence in Ancient Mediterranean France.

Patrice De Beer, (2006). "France's Immigration Myths". [Online at]: http://www.opendemocracy.net/content/articles/PDF/3252.pdf

Patrick Weil, (2006). A Nation in Diversity: France, Muslims and the headscarf. [Online at]: http://www.opendemocracy.net/content/articles/pdf/1811.pdf

Tariq Mahmood, (2013). Multiculturalism and Muslims in Britain and France: [Online at]: http://www.publicspirit.org.uk/multiculturalism-and-muslims-in-britain-and-france/

Thomas L. Harper (2011). 6 Volume 04.

UNHCR (2006): Asylum levels and trends in industrialized countries 2005. Geneva.

Weil, P. (1995): La France et ses étrangers. Paris: Gallimard. Country Profile No. 2 France 